\title{
INSTITUTIONAL CARE SYSTEM TRANSFORMATION: TRENDS AND PERSPECTIVES FOR THE DEVELOPMENT OF CHILD CARE INSTITUTIONS
}

\author{
Janina Čižikienè \\ Mykolas Romeris University, Lithuania
}

\begin{abstract}
This article analyses the transformation of the social childcare system in Lithuania, which aims at eliminating institutional childcare homes by the year 2020 and the placement of parental care for children in families of adoptive parents and carers, and returning them to biological parents. However, during the transition period, patronage impairment is noticeable, and municipalities choose an intermediate option and place children in community homes that provide short-term or long-term social care. It provides social services to a social care institution, in which the community in a separate room (house, apartment) family-friendly environment model houses up to 8 children in the home environment. When providing social services to parental care, it is necessary to understand the importance of deinstitutionalisation in the system of social services and to model their activities towards the home environment, bearing in mind that the process of deinstitutionalisation involves a change in the formation of a permanent custody, the services that best suit the individual interests of each child, taking into account their needs for growth and improve. This can only be achieved by improving the human resources capabilities of social service organizations by providing the right knowledge to provide tailor-made services based on results-oriented work principles.

Applied research methods are analysis of scientific literature and documents, interviews with social workers of a community nursing home, analysis and interpretation of research results. The review of scientific literature and research data presented in the article reveal the problems of the institutional care transformation process and the challenges of transforming the children's care homes and developing the activities of community child care homes.
\end{abstract}

Keywords: child custody, deinstitutionalisation, community child care home.

\section{Introduction}

Lithuania has ratified the United Nations Convention on the Rights of the Child, to take all necessary legislative, administrative and other measures to ensure compliance with and implementation of all Convention rights of the child enshrined. Native and one of the most important rights of the child are to grow up in the family. The family provides the best conditions for the full development of the child, but often parents are unable to take care of their child, forgetting their 
duties, thereby depriving the child of the right to grow with them and protect the legitimate interests of their children. The reasons for the loss of parental care may be: objectives, when both parents or single parents are dead, both parents are unknown, the only parent is either alone or both parents are missing and one of them is ill, arrested, sentenced or other important reasons, the child is separated from the parents by law, the child's parents (father or mother) in accordance with the established procedure in the manner prescribed by law, temporarily or indefinitely restricted by the authority of the parent (father or mother); subjective when parents or the sole parent are not cared for, unattended, neglected, misused, used by physical or psychological violence, etc.). Parental care must be taken care of, parents must be able to live in a nearby home environment, and essential needs are met.

The issues of parental care were analysed by Ryan, Perron, Huang (2016), Biehal (2014), parental separation and placement in care institutions was analysed by Day and ect. (2015), aspects of the education of children living in residential care institutions was analysed by Gudonis, Butkutè, Samašonok (2008), Samašonok (2013), aspects of deinstitutionalisation of care institutions Buster, (2012), Dunajevas (2012), Gvaldaite, Šimkonyte (2016). The effectiveness of social support for the family was analysed by Lazutka, Žalimiemé, Skučienè, Ivoškaitè-Tamašiūnė, Šumskaitė (2008), Krankalis, Dumskytė (2012), Dunajevas (2011), Žalimiené, Dunajevas (2015), social support Thompson (2015), the impact of social support and social services on individual groups of beneficiaries was analysed by Čižikienè, Virbalienè (2016). Social support for family and children was analysed by Gražulis, Čižikienè (2016).

The aim of the article is to review the peculiarities of the institutional care system's transformation and to evaluate the ongoing process of deinstitutionalisation in the system of social services by reorganizing children's care institutions in Lithuania. To achieve the goal, the following tasks were set: to describe the situation of the child's social care; review the peculiarities of the process of deinstitutionalisation; to analyse the conditions for the development of community child care homes.

\section{The situation of the Child's Social Care in Lithuania}

Lithuania's strategy "Lithuania 2030" calls for the strengthening of the family institute to create a family-friendly environment: to expand the system of complex services and infrastructure for the family, to create favourable conditions for the implementation of the family procreative function and to form a positive 
attitude of the society towards the family. The state has an obligation to take care of the family as an important value for the whole society, to implement an effective family policy that properly and effectively protects and supports the family, provides favourable conditions for raising children. Article no 38 of the Constitution of the Republic of Lithuania states that "the family is the basis of society and state. The state protects and cares for the family, motherhood, fatherhood and childhood." However, there are families unable to adapt to the rapidly changing economic conditions that cannot solve their problems independently and take care of the future of the children; thus, socially excluded families and children need to get social support, not only to meet the minimum needs for social risk, but also to ensure proper family protection (Gražulis \& Čižikienè, 2016).

One of the help measures is the provision of social services that provide assistance to a person (family) due to age, disability, partly or wholly unprofitable social problems, who have not acquired or lost their abilities or opportunities to take care of their personal (family) life independently and participate in society (LR Social ..., 2006). Thus, the services provided to children are provided for custody where the child is disabled and the need to develop his autonomy when the child is begging, abusing psychotropic substances, experiencing violence in a nearby environment, and failing to ensure the successful development. In solving the problems faced by the child, social care is provided, which includes the whole of services, providing complex assistance to the child and constant supervision of specialists, thus the recipients of social services are children with disabilities, children who have lost parental care, children at social risk. Looking at social care statistics (see Table 1), we can see the main reasons why children are being cared for is parental neglect, child neglect, inadequate parenting. Unfortunately, the data shows that the number of children deprived of parental care per year is not decreasing. Therefore, these children need a comprehensive and comprehensive help that would adjust and reduce the negative life experience and create conditions for the child's successful physical and psychological development. 
Table 1 Children who have custody due to custody reasons

\begin{tabular}{|c|c|c|c|c|c|}
\hline & 2013 & 2014 & 2015 & 2016 & 2017 \\
\hline $\begin{array}{l}\text { During the year, children lost parental } \\
\text { responsibility, in total }\end{array}$ & 2112 & 1871 & 1837 & 2184 & 2402 \\
\hline \multicolumn{6}{|l|}{ of them by reasons: } \\
\hline $\begin{array}{l}\text { parents did not take care, did not care about the } \\
\text { child's interests, did not oversee him, improperly } \\
\text { educated (2006-2010) and used violence }\end{array}$ & 1522 & 1309 & 1288 & 1628 & 1894 \\
\hline parental authority restriction & 45 & 40 & 29 & 31 & 19 \\
\hline children became orphans & 114 & 111 & 127 & 82 & 52 \\
\hline $\begin{array}{l}\text { the child is separated from the parents by the } \\
\text { procedure established by law }\end{array}$ & 49 & 34 & 34 & 29 & 18 \\
\hline parents are missing and sought & 3 & 13 & 5 & 4 & 5 \\
\hline parents recognized as incapable & 2 & 1 & 1 & 2 & 1 \\
\hline parents are incapable minors & 51 & 78 & 61 & 62 & 56 \\
\hline $\begin{array}{l}\text { paternity or close kinship relationship is not } \\
\text { established within three months from the date of } \\
\text { the child's discovery }\end{array}$ & 12 & 7 & 9 & 12 & 9 \\
\hline Parents by court declared dead or missing & - & 1 & - & 1 & 1 \\
\hline $\begin{array}{l}\text { Parents were temporarily unable to care for the } \\
\text { child }\end{array}$ & 359 & 325 & 320 & 420 & 469 \\
\hline
\end{tabular}

Source: Lithuanian Department of Statistics www.osp.stat.gov.lt

The State periodically reports to the United Nations Committee on the Rights of the Child on the implementation of the provisions of the Convention in Lithuania, as well as verification of compliance with the commitments undertaken. The Committee, recalling the General Assembly of the United Nations in 2009, December 20 Annex 64/142 to the resolution "Alternative child custody guidelines" recommended that Lithuania: ensure sufficient opportunities for children who have left the family environment with alternatives to custody in the family or community; ensure that referral to a care institution is only a last resort and that the following criteria should be taken into account when determining whether a child should be taken to a care institution: adequate protection measures, obvious need and best interests of the child; establish clear guidelines and criteria for limiting parental authority and continuously review and monitor all cases of childcare facilities; the strict framework for the supervision of care institutions, in particular non-state-based services, should take into account the Common European Framework for the transition from institutional to 
Institutional Care System Transformation: Trends and Perspectives for the Development of Child Care Institutions

community-based care and quality standards and use EU funding to strengthen the implementation of their legal provisions.

When assessing the tendencies and problems of ensuring the interests of parents who lost their parental care in the area of institutional care of the child, it needs to be noted that the Government of the Republic of Lithuania in 2007, approved the strategy for the reorganization of the system of child care. The Action Plan foresees to reduce the number of parental care children by $1 \%$ from the total number of children by 2012 and to achieve a reduction in the number of children in institutions by $30 \%$ by 2012 (Valstybinio...., 2014). When analysing statistics, (see Table 2) it can be stated that the goal was not achieved.

Table 2 Children without parental care by placement

\begin{tabular}{|c|c|c|c|c|c|}
\hline & $2013 * *$ & $2014 * *$ & $2015 * *$ & $2016 * *$ & 2017** \\
\hline $\begin{array}{l}\text { During the year, children lost } \\
\text { parental responsibility, in total }\end{array}$ & 2112 & 1871 & 1837 & 2184 & 2402 \\
\hline \multicolumn{6}{|l|}{ of which care is determined: } \\
\hline in families & 834 & 878 & 824 & 935 & 1228 \\
\hline communal families & 51 & 41 & 38 & 53 & 65 \\
\hline in baby home & 129 & 148 & 199 & 227 & 66 \\
\hline in state child care home & 100 & 98 & 53 & 56 & 33 \\
\hline $\begin{array}{l}\text { in institutional care for disabled } \\
\text { children and young people }\end{array}$ & 6 & 5 & 3 & 1 & 3 \\
\hline $\begin{array}{l}\text { in general education and special } \\
\text { schools, special education centres* }\end{array}$ & 19 & 20 & 22 & 6 & 0 \\
\hline in municipal child care homes & 797 & 539 & 606 & 748 & 773 \\
\hline in municipal child care groups & 104 & 93 & 29 & 64 & 42 \\
\hline $\begin{array}{l}\text { public organizations and parish } \\
\text { children's care homes }\end{array}$ & 117 & 93 & 104 & 153 & 200 \\
\hline
\end{tabular}

Source: Lithuanian Department of Statistics www.osp.stat.gov.lt

*General education, special schools and special education centres that have cared for a child or provide social services with accommodation.**The number of children in custody (care) per year and the number of children deprived of parental care varies, as not all children who lost their parental care at the end of the year were given to custody (care).

The transition from institutional care to family and community services for the disabled and the children without parental care for the 2014-2020 action plan (LR Social ...., 2014) indicated that the target is during 2014-2020, to provide coherent and coordinated actions to promote the transition from institutional 
social care to children and young people with a mental disability and the development of a caregiver system for the rest of the children, including infants, families in the community and family support, caregivers. The aim of which is to create a system of integrated services that would enable every child, disabled person or his family (carers) to receive tailored services and community assistance.

Implementing the measures for the transition from institutional care to family and community services for the disabled and the children without parental care for the 2014-2020 action plans, child restraint institutions reorganize and establish community-based child care homes. 2018 According to the data, 84 communitybased children's homes are functioning in the country, and 490 children live there. The main goal of a community child care home is to provide child care and social services, to create suitable conditions for them and to maintain an environment in which the child can grow safely and develop and prepare for independent life in society. Educational activities of such care homes should be aimed at fostering children's social competences, which will help them to adapt successfully to society, to integrate into it and to live an active and full-fledged life.

\section{Aspects of the Process of De-institutionalization}

In the course of de-institutionalization, the transition from institutional to community-based services is a complex, resource-intensive, two-way process that involves disrupting the old institutional order and creating a new, communitybased one. The changes in the transformation can be explained by the institutional aspect of the theory, which analyses the relationship between regulation of the organization and its surroundings (regulatory), normative and cognitive elements (DiMaggio \& Powell, 1983). The institutional influence in organizations comes from the formulation of rules and regulations, normative guidance and social expectations (Scott, 2001). Organizations are also affected by institutional logic, which is defined as a social construct that affects the behaviour of individuals, including the creation of assumptions, values, beliefs and norms (Thornton et al., 2012). It has been established that social acceptance is gained through the internal organization's harmony and unity among stakeholders, but conflicting interests in the external environment have been viewed as posing a danger that the environment actually establish institutional pluralism and compromise institutional requirements for organizations (Battilana \& Dorado, 2010). The possibility of changes in the institutional structure arises through external and internal factors. Offe (2006) distinguishes the following sources of institutional 
Institutional Care System Transformation: Trends and Perspectives for the Development of Child Care Institutions

change: the need for a review of existing agreements or institutions arises when changing power relations between actions; demographic or technological; inconsistencies between individual institutional structures. Institutional change may occur in the following directions: institutional change, stratification, downstream, surface (Mahoney \& Thelen, 2009). Institutional displacement means that the existing institutional set-up is being dismantled or undergoing a de-institutionalization process and introducing a new institutional structure or institutionalization process. Institutional layering represents the introduction of new institutions without undermining the existing ones. Drift refers to the fact that changes in external circumstances do not result in institutional changes, which can lead to substantial changes over time. Surface conversion - existing institutions are reinterpreted, resulting in a new action (Dunajevas, 2011). The authorities are opposed to any changes and any initiatives to change their established rules. In the 1960s, de-institutionalization processes in developed countries began, with the need to reorganize the provision of social services. Its purpose was to give service users more power or a more important role in managing their daily lives (Dunajevas, 2012). In this process, community and residential care was combined to ensure the best interests of the client, therefore, institutionalism, as opposed to deinstitutionalisation, is due to its orientation towards stability rather than change. Therefore, no institution acting under institutional logic will have an interest in sacrificing its stability, prosperity and voluntarily not participating in the transformation process, and any intervention in the established order will act as a "threat to the institutional set-up" and will take measures to prevent any innovative change (Genienè \& Šumskienè, 2016).

Reviewing the theoretical aspects, Genienè and Šumskienè (2016), identifies these obstacles in the process of deinstitutionalisation: 1) The opinion is that the services provided by the institution are of high quality - a good material base is created, therefore considerable attention is paid to the large funds for the renovation of the buildings and the development of the material base and not the quality of services, the main thing is that the institution complies with social care standards, but insufficient attention is paid to the quality of the provided services; 2) During the restructuring period, there are two systems, starting with the provision of community-based services, decisions to close residential institutions without fully deciding how communal services will be provided and whether provision of these services will be ensured, community-based services provided in parallel with inpatient services, duplication of costs, establishments and community houses, as well as financing both stationary and community services; 3) In the new alternatives, an institutional culture is formed, because in order to 
maintain buildings and staff, newly created community services are not as different from the services provided by the institution.

Thus, analysing the process of transformation from the point of view of institutional theory can explain why the system is in a state of uncertainty, while processes of deinstitutionalization are slow, the planned results are negligible. Gvaldaite, Šimkonyte (2016) argues that a great deal of workers' resistance to deinstitutionalisation processes is taking place, as many of them do not trust the intended restructuring, they have many questions, they are insecure, afraid of their future, they lack clarity. The purpose of the empirical research will be to find out the approach of social workers working in the child care system to the transformation of care institutions in the context of deinstitutionalisation.

\section{Research Methodology}

The problem of research - in carrying out the plan for the transition from institutional care to family and community services for the disabled and for those without parental care for children, it is important to clarify the causes of the problems of the restructuring of care institutions and to provide possible options for improvement.

The object of the research is the possibilities of activity of care institutions in the process of deinstitutionalisation.

The purpose of the study is to reveal the aspects of the activities of community care institutions in implementing the transition from institutional care to family and community services.

The tasks of the empirical research are: 1 ) to conduct an opinion poll of social workers, which would help to identify the challenges of the transformation of care institutions; 2) to propose ways and means to stimulate and implement deinstitutionalisation process in care institutions. A qualitative research method was chosen for the empirical research - a survey of social workers' opinion in the form of a structured questionnaire (interview). Attract criteria: social work experience not less than 5 years; experience working in a child care institution. The study involved 5 social workers. The study was conducted through a formal interview, i.e. Interviews on pre-arranged questions that were asked to all respondents in the same order. This form of interview was chosen to clarify the opinion on the current situation. A pre-prepared questionnaire consists of a group of interrelated questions answered by the interviewees. Problematic issues: How do you evaluate the Lithuanian custody system? How do you rate the 
Institutional Care System Transformation: Trends and Perspectives for the Development of Child Care Institutions

transformation of care institutions in the context of deinstitutionalisation? What measures and changes should improve the care system?

The study took place in 2018, May-July. The study provides preliminary data obtained during this study, and more quantitative studies are needed to obtain more accurate and more reliable information.

\section{Research Results}

During the interview, social workers were asked to evaluate the current care system in Lithuania: "there are still large state-owned care institutions, which, as it is supposed, will be shut down by 2020, will this be?"; "Lithuania's custody system still remains post-Soviet and, in many cases, does not conform to European standards"; "it was hoped, that by 2015, there would be no institutions in Lithuania that would have more than 40 custodians"; "if there were children in institutions - the amount will remain quite high, it will be difficult to assess the personal needs of the child”; "Children growing up in large institutions do not have sufficient individual attention"; "they do not acquire sufficient skills for independent living”.

Respondents indicate that there is, not yet, a complete transition to community-based services and points to problems about living in large residential institutions. All respondents in the study state that the transition to communitybased services is necessary and evaluated positively: "Currently, there is a transition from institutional care to family and community services. I appreciate this process positively"; "when talking about NGOs we see a small family of up to 8 children"; "employees with children create a close relationship based on trust"; "living environment is closer to home and family model"; "children living in a close family environment receives more individualized services geared towards the child's weaknesses"; "life in smaller settings, families or communal families is much more in line with the child's needs for a family in a close environment".

It was important to find out the informants' attitude to the transformation of care institutions in the context of deinstitutionalisation. Informant observes the progressive nature of the ongoing process and appreciates positively: "deinstitutionalisation is a gradual process, which involves not only the closure of large care institutions, but also the creation of high-quality alternative social services", "in the process of deinstitutionalization, fewer children will go to care institutions"; "I appreciate deinstitutionalisation positively". Informants are looking at and pointing to the following problems related to the reorganization of 
the care institution: "For the time being, deinstitutionalisation does not succeed in Lithuania"; "everything is happening in a hurry, because it is supposed to be guided by 2020"; "there is a sudden rush, and it can harm children"; "there is a danger that children will be mechanically raised, bigger children will not always experience positive changes"; "in a hurry to change the already established lifestyle and rules, children will be left in their biological families, irrespective of the real situation, in order to reduce the number of institutions in small towns and cities"; "there can be various ways of reducing the number of children .... Doing better, and as always, children with special needs should be taken into account, because the dismantling of large institutions where the necessary specialists worked, complicates the availability of necessary services". Summarizing the answers received, it can be stated that the process of deinstitutionalisation is more formal than the real one, it is spoken about, an opinion is being developed, but in general, the situation with the large institutions of care is changing hard, the number of children in the guardianship is not decreasing, there are no families who would like to temporarily sponsor teenagers and special needs of children.

The study sought to diagnose disorders of deinstitutionalisation, informs them and points out: "There is currently no clear legal framework for how to work properly according to the new deinstitutionalized procedure"; "the number of families who are supportive to adolescents, children with emotional disorders, mental disorders is slowly developing, there is no strong support for the family model", "there is no strong education and social work specialists or a team of psychologists to deal with crisis situations"; "the question of financing such a family is unclear"; "small salaries of employees does not attract good specialists"; "deinstitutionalisation may be difficult because of the negative attitudes of communities for the adoption of disabled people or children from residential care homes (for example, they do not want to rent apartments)". It can be argued that during the transition period there are loopholes in the legal regulation, and insufficient financing hinders implement the process, as well as the respondents emphasize the negative attitude of the society towards the children and the reluctance to live in a close environment.

It was important to find out how this process can be fostered and deinstitutionalisation of care institutions could be identified, respondents identify the following: "A clear legal and financial framework must be created"; "must be prepared by mobile teams of professionals"; "need appropriate professionals to help solve crisis situations in families and community care homes who have taken care of a child"; "there must be clear requirements for community-based care homes built in private apartments or houses"; "workers must be 
Institutional Care System Transformation: Trends and Perspectives for the Development of Child Care Institutions

continuously trained"; "employees from major state institutions must not be moved to smaller but retrained work with children in community care units at home where the environment is informal and family-friendly"; "to allocate more money to employees' salaries"; "to educate society". The answers have shown, and it can be argued that a successful legal process requires: a clear regulatory framework, adequate human resources management, training and retraining, and public awareness of the positive effects of transformation on the development of children.

The survey evaluated the respondents' opinion on the prospects and possibilities of improving care institutions. Informants say: "the care system must be deinstitutionalized"; "there must be a clear framework for funding, emotional and legal support"; "families have to have the types: the children with permanent care should live together so that there is no significant change in the group so that children feel emergency-safe"; "institutions providing temporary care together with specialists in the field of child protection and employees of suburbs should work with the whole family, provide emotional support, see the real situation and provide conclusions about the possibility of a child returning to the family"; "custody should take care after 6 children"; "psychologist should always work with children".

To sum up, it can be said that in the process of deinstitutionalisation, the transition to community services is necessary and evaluated positively. Visibility, resistance to change, slow transition make it possible to assume that there is a lack of public support and developed community services that would ensure new needs and requirements in the ongoing process of de-institutionalization, as the number of child carers is not decreasing, there are no families who would like to temporarily sponsor teenagers and children with special needs. For successful restructuring, it is necessary to review the legal framework, choose the right human resources management, training and retraining, and keep the public informed about the positive impact of transformation on the development of children.

\section{Conclusions}

It has been determined that the number of children left without parental care in Lithuania shows an inadequate level of assistance to the family, enabling it to take care of the child independently, and also insufficiently takes into account the individual needs of the family in providing social services. 
It is necessary to promote the change in the values of society's values by developing a positive attitude of the society towards the transformation of the care system, showing the positive aspects of the ongoing process. People are afraid that children in their neighbourhood will have children with negative experiences in their lives by having behavioural, emotional disturbances, tend to commit crimes, so it is very important to form an opinion that these children are no different from their peers, they are the same citizens of our country and only from the efforts of the community for them, the socialization process for these children will be smooth. As there is a shortage of carers during the transition period, municipalities have to plan and accommodate children in community care homes that provide short-term or long-term social care. The establishment and development of community nursery homes is essential for a family life model, while living in these homes of this type, children have the opportunity to learn to live in close proximity to others, to democratically solve difficulties, to test and consolidate practical life skills. Working in such a home is based on trust, understanding the needs and opportunities of each child by establishing an appropriate individual care plan. A maximum of six children (although currently accommodating eight children) could live in community custody homes, with which employees would build a stable and trust-based relationship.

\section{References}

Battilana, J., \& Dorado, S. (2010). Building sustainable hybrid organizations: The case of commercial microfinance organizations. Academy of management Journal, 53(6), 14191440 .

Biehal, N. (2014). A Sense of Belonging: Meanings of Family and Home in Long-Term Foster Care. British Journal Of Social Work, 44(4), 955-97.

Buster, M. (2012). De-institutionalisation. Hope and homes for children. Retrieved from http://www.openingdoors.eu/wpcontent/uploads/2013/05/DI_Myth_Buster.pdf

Čižikienè, J., \& Virbalienè, R. (2016). Social pedagogical assistance at school: performance analysis. Society, integration, education: proceedings of the international scientific conference, May 27th-28th. 3, 271-281.

Day, A. G., Somers, C., Smith Darden, J., \& Yoon, J. (2015). Using Cross-system Communication to Promote Educational Well-being of Foster Children: Recommendations for a National Research, Practice, and Policy Agenda. Children ir Schools, 37(1), 54-62.

DiMaggio, P. J., \& Powell, W. W. (1991). The New Institutionalism in Organizational Analysis. Chicago: University of Chicago Press

Dunajevas, E. (2011). Asmeniniu socialiniu paslangu sistemos raida pokomunistineje Lietuvoje. Daktaro disertacija. Vilnius: VU. 
Institutional Care System Transformation: Trends and Perspectives for the Development of Child Care Institutions

Dunajevas, E. (2012). Asmeninių socialinių paslaugų deinstitucionalizacija pokomunistinèje Lietuvoje, STEPP, 6, 45-63.

Europos Sajungos fondu panaudojimo perëjimui nuo institucinès prie bendruomeninès globos priemoniu rinkinys (2012). Briuselis: Europos ekspertų grupé perẻjimo nuo institucinès prie bendruomeneje teikiamos globos klausimais

Genienè, R., \& Šumskienè, E. (2016). Stacionarios globos pertvarka Lietuvoje institucionalizmo teorijos požiūriu. Socialinè teorija, empirija, politika ir praktika, 12, 73-80.

Gražulis, V., \& Čižikienè, J. (2016). Evaluation of non-financial social assistance to families in child day care centers: situation analysis in Lithuania. Acta Prosperitatis, 7, 59-73.

Gudonis, V., Butkutè, I., \& Samašonok, K. (2008). Globos namų auklètinių ir paauglių, gyvenančių pilnose šeimose, adaptacijos ypatumai. Specialusis ugdymas, 2 (19), 8-21.

Gvaldaitè, L., \& Šimkonytė, S. (2016). Vaikų globos namų deinstitucionalizacija Lietuvoje: ar „vežimas” judès ị priekị? Socialinè teorija, empirija, politika ir praktika, 12, 55-73.

Jungtinių Tautų vaiko teisių konvencija. Valstybès žinios, 1995, No.60-1501. Retrieved from https://unicef.lt/wp-content/uploads/2017/06/JT-Vaiko-Teisi\%C5\%B3-Konvencija.pdf

Krankalis, R., \& Damskytė, J. (2012). Piniginès socialinès paramos administravimo ypatumai atokiame kaimiškame rajone: Akmenès rajono atvejo analizè. Ekonomika ir vadyba: aktualijos ir perspektyvos, 3 (27), 27-36.

Lazutka, R., Zalimiene, L., Skučienė, D., Ivoškaitè-Tamašiūnè, V., \& Šumskaitè, L. (2008). Socialine parama Lietuvoje: remiamuju padetis ir paramos rezultatai. Vilnius: Lietuvos socialinių tyrimų centras

Lietuvos Respublikos Konstitucija (1992). Valstybès žinios. No. 33-1014.

Lietuvos Respublikos Konstitucinis Teismas. Dèl Lietuvos Respublikos Seimo 2008 m. birželio 3 d. nutarimu No. X-1569 „Dèl valstybinès šeimos politikos koncepcijos patvirtinimo” patvirtintos valstybinès šeimos politikos koncepcijos nuostatu atitikties Lietuvos Respublikos Konstitucijai. (2011). Valstybès žinios, No. 118-5564.

Lietuvos pažangos strategija „Lietuva 2030”. (2012). Valstybès žinios, No. 61-3050.

Lietuvos Respublikos socialinių paslaugų įstatymas (2006). Valstybès žinios. No. 17-589.

Lietuvos Respublikos šeimynų įstatymas (2010). Valstybès žinios. No. 25-1176.

Lietuvos Respublikos vaiko gerovès valstybès koncepcija (2003). Valstybès žinios. No. 9-1569.

Lietuvos Respublikos vaiko laikinosios globos (rūpybos) nuostatai (2007). Valstybès žinios. No. A1-145.

Lietuvos Respublikos Vaiko teisių apsaugos pagrindų ịstatymas (1996). Valstybès žinios. No. I-1234

Lietuvos Respublikos Dèl vaiko globos (rūpybos) sistemos reorganizavimo strategijos ir jos igyvendinimo priemonių 2007-2012 metų plano patvirtinimo (2007). Valstybės žinios. No. 118-4817.

LR socialinès apsaugos ir darbo ministro įsakymas dèl neigalių vaikų, likusių be tèvų globos vaikų, suaugusių neigalių asmenų socialinès globos namų deinstitucionalizacijos strateginių gairių patvirtinimo (2012). Valstybės žinios. No, A1-517.

LR socialinès apsaugos ir darbo ministro ịsakymas dèl perẻjimo nuo institucinès globos prie šeimoje ir bendruomenejje teikiamų paslaugų neigaliesiems ir likusiems be tèvų globos 
vaikams 2014-2020 metų veiksmų plano patvirtinimo (2014). Valstybès žinios. No. A1-83.

LR Vaiko teisių apsaugos kontrolieriaus 2017 metų veiklos ataskaita (2018). Retrieved from http://www.vtaki.lt/lt/administracine-informacija/veiklos-ataskaitos

Lietuvos Statistikos departamentas. Gyventojai ir socialinè statistika. Socialinè apsauga (pagal ESSPROS). Retrieved from http://osp.stat.gov.lt/rodikliai21

Mahoney, J., \& Thelen, K. (2009). “Instroduction”, in James Mahoney and Kathleen Thelen (Eds.). Explaining Institutional Change. Ambiguity, Agency, and Power. Cambridge.

Offe, C. (2006). „Political Institutions and Social Power: Conceptual Explorations” in Ian Shapiro, Stephen Skowronek, Daniel Galvin (Eds.). Rethinking Political Institutions: The Art of the State. New York University

Pūras, D. (2010). Instituciné globa - vaiku iki trejų metu amžiaus teisiu pažeidimas. United Nations of Human Rights. Retrieved from https://www.hrmi.lt/uploaded/PDF\%20dokai/ LT_D.Puras_Children\%20under\%203.pdf

Ryan, J., Perron, B., \& Huang, H. (2016). Child Welfare and the Transition to Adulthood: Investigating Placement Status and Subsequent Arrests. Journal Of Youth \& Adolescence, 45(1), 172-182.

Samašonok, K. (2013). Globos namuose gyvenančių vaikų ir paauglių savarankiško gyvenimo igūdžių ugdymas: pasiekimai, sunkumai, sprendimai. Pedagogika, 110, 103-114.

Scott, J. (2001). Power. Polity Press

The Committee, recalling the General Assembly of the United Nations in 2009, December 20 Annex 64/142 to the resolution "Alternative child custody guidelines" (accessed on 10.09.2018):

http://www.un.org/en/development/desa/population/migration/generalassembly/docs/gl obalcompact/A_RES_67_152.pdf.

Thompson, R. A. (2015). Social Support and ChildProtection: Lessons Learned and Learning. Child Abuse \& Neglect, 41, 19-29.

Thornton, P. H., Ocasio, W., \& Lounsbury, M. (2012). The institutional logics perspective: A new approach to culture, structure and process. New York: Oxford University Press.

UNICEF (2010). At Home or in a Home?: Formal Care and Adoption of Children in Eastern Europe and Central Asia.

Valstybinio audito ataskaita. „Ar vaiko globos sistema atitinka globojamo vaiko geriausius interesus? (2014). Vilnius: Socialinès apsaugos ir darbo ministerija

Žalimienè, L., \& Dunajevas, E. (2015). Socialinès paramos dilema: tarp autonomijos ir paternalizmo. Vilnius: VU leidykla.

Žalimienè, L. (2015). Šeimos paramos politika Lietuvoje: ar galime identifikuoti paradigminius pokyčius 1996-2013 metų laikotarpiu? TILTAI, 1, 39-61. 